\title{
The role of tubificid worms (Limnodrilus hoffmeisteri) in sediment resuspension: a microcosm study
}

\author{
Lei Zhang ${ }^{1}$, Jingge Shang ${ }^{2}$, Wei He${ }^{3}$, Bensheng You ${ }^{1}$ and Chengxin Fan ${ }^{1 *}$ \\ ${ }^{1}$ State Key Laboratory of Lake Science and Environment, Nanjing Institute of Geography and Limnology, Chinese Academy \\ of Sciences, Nanjing 210008, People's Republic of China \\ 2 Department of Environmental Science, China Pharmaceutical University, Nanjing 211198, People's Republic of China \\ 3 Shanghai Investigation, Design and Research Institute, Shanghai 200434, People's Republic of China
}

Received 9 February 2014; Accepted 25 June 2014

\begin{abstract}
Sediment resuspension is an important internal lake process in regulating nutrient cycling and ecosystem structure. Tubificid worms are widely and abundantly distributed in freshwater ecosystems and are able to alter the sediment characteristics. This study was conducted to verify the hypothesis that the alteration of sediments by tubificids may substantially influence the sediment resuspension process. Specifically, we investigated the influence of Limnodrilus hoffmeisteri (Tubificidae) on sediment resuspension using an apparatus designed to simulate the sediment resuspension process in Lake Taihu (China). We examined L. hoffmeisteri according to its density (30000 ind. $\mathrm{m}^{-2}$ ) in Lake Taihu and simulated the light (3.2 m.s $\left.\mathrm{s}^{-1}\right)$, moderate $\left(5.1 \mathrm{~m} . \mathrm{s}^{-1}\right)$ and strong $\left(8.7 \mathrm{~m} . \mathrm{s}^{-1}\right)$ wind processes present in Lake Taihu. Tubificids loosened the sediment through their feeding and defecation activities and increased the sediment water content. The appearance of tubificids increased the suspended solids (SS) in a $1.6 \mathrm{~m}$ water column under all three wind processes. During the sedimentation process, SS decreased rapidly in both the control and tubificid treatments. The total SS in the water column was significantly increased by tubificids and it changed significantly with time. In addition, the small size particles of the SS in the tubificid treatment were higher than that in the control. So, the appearance of tubificid worms (L. hoffmeisteri) enhanced sediment resuspension and raised the proportion of small size particles in SS.
\end{abstract}

Key words: Sediment resuspension / suspended solids / tubificid worm / benthic animal / Lake Taihu

\section{Introduction}

Sediment resuspension refers to the redistribution process of sediment particles that have settled on the bottom back into the overlying water column, a process that can occur repeatedly (Bloesch, 1995). The increase of particles in the water column causes light attenuation and decreases the water transparency (James et al., 2004; Sorokina and Kulygin, 2013). Accompanying sediment resuspension are an enhanced exchange between the porewater and overlying water and the adsorption and desorption of resuspended particles, factors that influence phosphorus and nitrogen cycling across the sediment-water interface (You et al., 2007b; de Vicente et al., 2010; Kalnejais et al., 2010; Couceiro et al., 2013; Tammeorg et al., 2013). Consequently, the plankton

*Corresponding author: cxfan@niglas.ac.cn; laoshuldudu@ 163. com and ecological structure in aquatic ecosystems are also changed (Schallenberg and Burns, 2004; Song et al., 2010; Kang et al., 2013). In addition, the transportation of metals and toxic organic pollutants in aquatic ecosystems are profoundly impacted by resuspension (Yang et al., 2008; Kalnejais et al., 2010; Superville et al., 2014). Sediment resuspension is thus an important process in both limnology and environmental science.

Sediment particles are resuspended when the bottom shear stress exceeds the critical shear stress of the sediment bed (Evans, 1994; Bloesch, 1995). The critical stress is usually referred to as sediment erodibility, which is dependent on the physical (e.g., particle size, bulk density and water content), geochemical (e.g., organic content, clay mineralogy and $\mathrm{pH}$ ) and biological properties of the sediment bed and the interactions among multiple properties (Grabowski et al., 2011). Benthic animals live in or on the sediment, and the presence, feeding and egestion 
of these organisms produce structures (burrows, networks and biofilms) and substances (feces/pseudofeces and clusters), all of which influence the biological properties of the sediment (Widdows and Brinsley, 2002; Grabowski et al., 2011).

Some bivalves, snails, polychaete worms and ghost shrimp decrease the critical shear stress of the sediment and increase sediment resuspension through increased sediment surface roughness and loosened sediment, and the mass of resuspended sediment is significantly correlated with the densities of these animals (Widdows et al., 2000, 2009; Sgro et al., 2005; Orvain et al., 2006; Amaro et al., 2007). However, the bivalve Mytilus edulis caused the highest sediment resuspension at a density of $25 \%$ of the sediment surface covered by the bivalve, and sediment resuspension decreased at bivalve densities above this level (Widdows et al., 2002). In addition, increased density of the brittlestar Amphiura filiformis decreased the suspended sediment load (Amaro et al., 2007). The bivalves Actinonaias ligamentina and Ptychobranchus fasciolaris did not influence the amount or particle size of suspended sediment (Zimmerman and de Szalay, 2007). Different taxa have distinct effects on sediment resuspension; thus, changes in the biotic community alter sediment erodibility (Widdows and Brinsley, 2002). Most published studies focus on invertebrates of relatively large size, although smaller invertebrates such as oligochaetes are also thought to influence sediment resuspension due to their ubiquity and high densities (Grabowski et al., 2011).

Tubificid worms are widely distributed in freshwater ecosystem and can accumulate in high densities in eutrophic waters (Matisoff et al., 1985; Cai et al., 2010). Tubificids are conveyor-belt feeders that ingest particles in deep sediments and egest them on the sediment surface in the form of pseudofeces (Kaster et al., 1984; Dafoe et al., 2011). The activities of these worms alter sediment stratification (Matisoff et al., 1999; Nogaro et al., 2007; Dafoe et al., 2011), increase sediment water content and porosity (Fukuhara, 1987; Zhang, 2010), change the distribution of the sediment particle size (Ciutat et al., 2006; Zhang, 2010; Dafoe et al., 2011) and alter the oxygen and nutrient dynamics in the sediment and across the sediment-water interface (Matisoff et al., 1985; Mermillod-Blondin et al., 2005; Zhang et al., 2010). Thus, we hypothesized that tubificids may influence the process of sediment resuspension. Lake Taihu is a shallow eutrophic lake located in the delta of the Yangtze River in China and has an area of $2338 \mathrm{~km}^{2}$ and a mean depth of approximately $1.9 \mathrm{~m}$ (Qin, 2008). Taihu is frequently influenced by winds, which induce the resuspension of sediment ( $\mathrm{Hu}$ et al., 2006; You et al., 2007a). Limnodrilus hoffmeisteri is the dominant tubificid worm in this lake, and it can achieve a density of up to 30000 ind. $\mathrm{m}^{-2}$ (Cai et al., 2010). In the present study, we aimed to investigate the influence of L. hoffmeisteri on sediment resuspension using an apparatus that was designed to simulate the sediment resuspension process in Lake Taihu.

\section{Materials and methods}

\section{Field sampling}

The sediment cores used for the experiment were collected from Meiliang Bay $\left(31^{\circ} 30^{\prime} 31.1^{\prime \prime} \mathrm{N}, 120^{\circ} 10^{\prime} 31.0^{\prime \prime} \mathrm{E}\right)$ in northwestern Lake Taihu. The surface sediment is constituted of $13.7 \%$ clay $(0.02-4 \mu \mathrm{m}), 69.8 \%$ silt $(4-63 \mu \mathrm{m})$ and $16.5 \%$ sand $(63-1000 \mu \mathrm{m})$. A gravity core sampler (11 cm internal diameter, $50 \mathrm{~cm}$ long, Rigo, Japan) was used to sample sediment cores. The sediment cores were stopped with rubber stoppers at both ends. Lake water was also collected with plastic barrels at the same time. A Petersen grab was used to collect the surface sediment to obtain tubificid worms. All samples were transported to the laboratory after they were collected.

\section{Microcosms}

To obtain uniform microcosms, the top $20 \mathrm{~cm}$ of each sediment core was sectioned in the laboratory into five layers of $4 \mathrm{~cm}$ depth. The same sediment portions from different cores were pooled together and sieved using a $0.6 \mathrm{~mm}$ mesh to exclude macroinvertebrates and large particles. Then, a dough mixer was used to fully homogenize each sediment pool. The five sediment pools were transferred in their original sequences and depths into six Plexiglas tubes ( $11 \mathrm{~cm}$ internal diameter, $30 \mathrm{~cm}$ long). Lake water was then added to the sediment surface in each microcosm using intravenous needles. Six microcosms with $20 \mathrm{~cm}$ of sediment and $10 \mathrm{~cm}$ of water were thus established. These microcosms were put into a water tank and submerged in lake water. The microcosms were preincubated for 1 month, after which they were randomly divided into two groups with three replicates. One group was assigned as the control (C) treatment, and no worms were added to this group. For the other group, 285 L. hoffmeisteri were introduced into each microcosm (30000 ind. $\mathrm{m}^{-2}$ ), and this group was designated as the tubificid ( $\mathrm{T}$ ) treatment. The experimental density of tubificids was based on their density in Lake Taihu (Cai et al., 2010). After the tubificids were introduced, all microcosms were incubated for 2 months to allow the worms to achieve a stable state in the sediment. During the incubation, the overlying water was replaced every 2 weeks. The water in the tank was maintained at $20 \pm 0.5^{\circ} \mathrm{C}$ with a circulator bath (Stik, China). To supply sufficient oxygen to the sediment and the worms, a miniaerator was placed in the water tank to maintain $\mathrm{O}_{2}$ saturation in the overlying water.

\section{Resuspension apparatus}

In the study, a Y-shape apparatus was used to simulate the sediment resuspension induced by winds (Fig. 1). The sediment core with several centimeters of overlying water was extruded from a cylinder into the apparatus (from the bottom). The sediment-water 


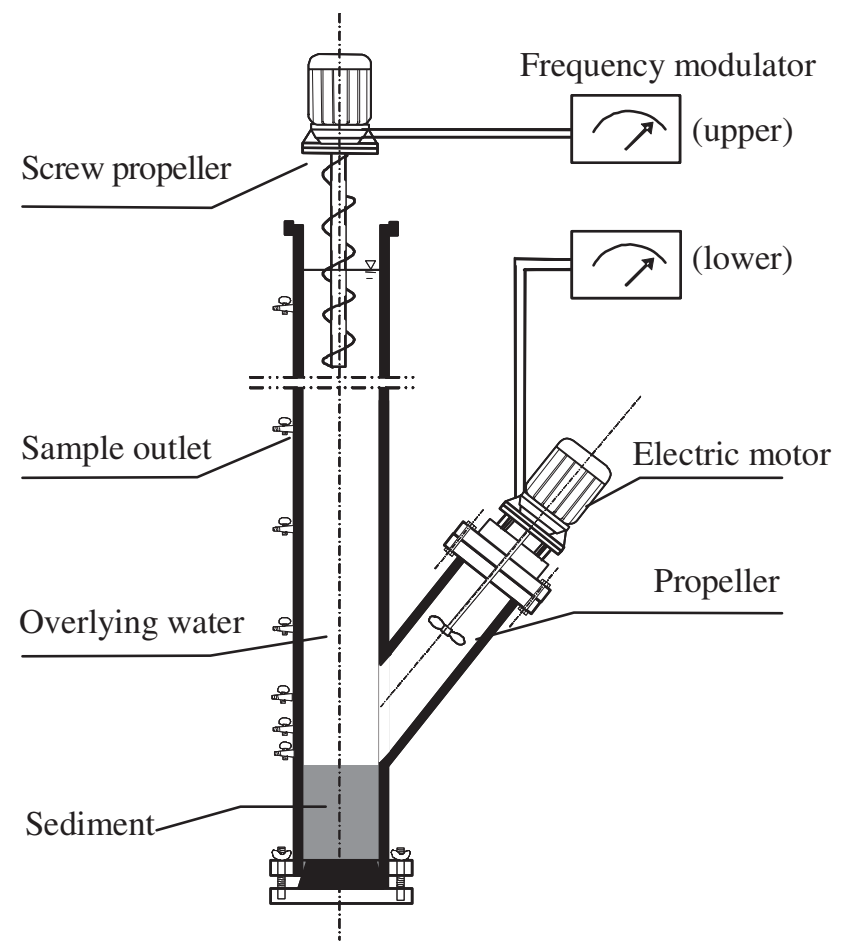

Fig. 1. Sketch of the Y-shape sediment resuspension apparatus.

interface was kept horizontal to the turning point of the oblique tube as illustrated in the sketch in Figure 1. Then, the bottom of the apparatus was stoppered with a flange. Lake water was gently transported into the tube above the sediment to a depth of $160 \mathrm{~cm}$. Shear stress was produced by the propeller on the electric motor of the oblique tube. The sediment particles were resuspended when the shear stress produced by the propeller exceeded the critical shear stress of the sediment bed. A screw propeller mounted inside the vertical tube $120 \mathrm{~cm}$ above the sediment-water interface was used to mix the water vertically. The rotating speeds of the two electric motors were separately controlled with a frequency modulator.

On the basis of the wind speed and the in situ observation of suspended solids (SS) in Lake Taihu (Hu et al., 2006), You et al. (2007a) established the relationship between the rotation frequency $(\mathrm{Hz})$ and wind speed $\left(\mathrm{m} . \mathrm{s}^{-1}\right)$ through repeated simulations of sediment resuspension in the Y-shape apparatus. Four wind conditions background, light, moderate and strong - were established on the basis of the wind speed and frequency at Taihu, with corresponding wind speeds of 1.7, 3.2, 5.1 and $8.7 \mathrm{~m} . \mathrm{s}^{-1}$, respectively. Corresponding to the four wind conditions, the respective rotation frequencies of the right motor were 5.8, 6.4, 7.1 and $8.4 \mathrm{~Hz}$. In the present study, we simulated three wind processes, light, moderate and strong wind processes. For each wind process, it was constituted of $1 \mathrm{~h}$ starting wind, $3 \mathrm{~h}$ experiment wind and $1 \mathrm{~h}$ ending wind. The background, light and moderate winds served as the starting and ending winds for the light, moderate and strong wind processes separately. Take the light wind process for example, the background
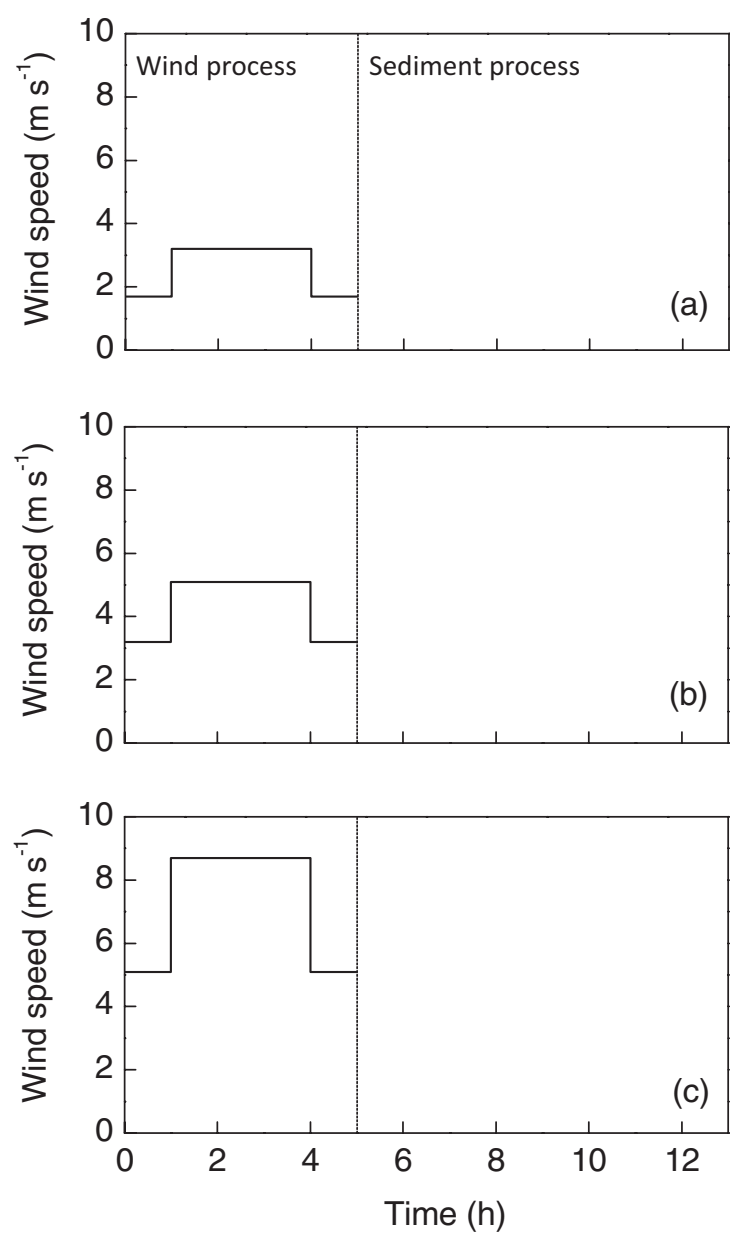

Fig. 2. Three simulated wind processes used to examine the influence of tubificid worms on sediment resuspension: light wind (a), moderate wind (b) and strong wind (c).

(starting) wind continued for $1 \mathrm{~h}$, then wind was raised to the light wind speed and lasted for $3 \mathrm{~h}$, then it was decreased to the background (ending) wind for $1 \mathrm{~h}$ (Fig. 2). The mean wind duration is about $3 \mathrm{~h}$ in Lake Taihu (You et al., 2007b); this is why we selected $3 \mathrm{~h}$ as the lasting time of experiment wind in the study. After each wind process, the sedimentation process was observed for the subsequent $8 \mathrm{~h}$. For details on the Y-shape apparatus and wind processes, see You et al. (2007a).

\section{Resuspension experiment}

Two months after the tubificids were added to the microcosms, the sediment surfaces of the $T$ treatment were disturbed slightly with a hand-held propeller to obtain a smooth surface because the worms had created a rough surface through their activities and excretions. The heights of the sediment cores were measured, and the effect of the worms on the sediment height was examined. Then, all sediment cores were extruded into the $\mathrm{Y}$-shape apparatus and lake water was added. An oxygen aerator was positioned $5 \mathrm{~cm}$ above the sediment-water interface to provide oxygen for the sediment and worms in 


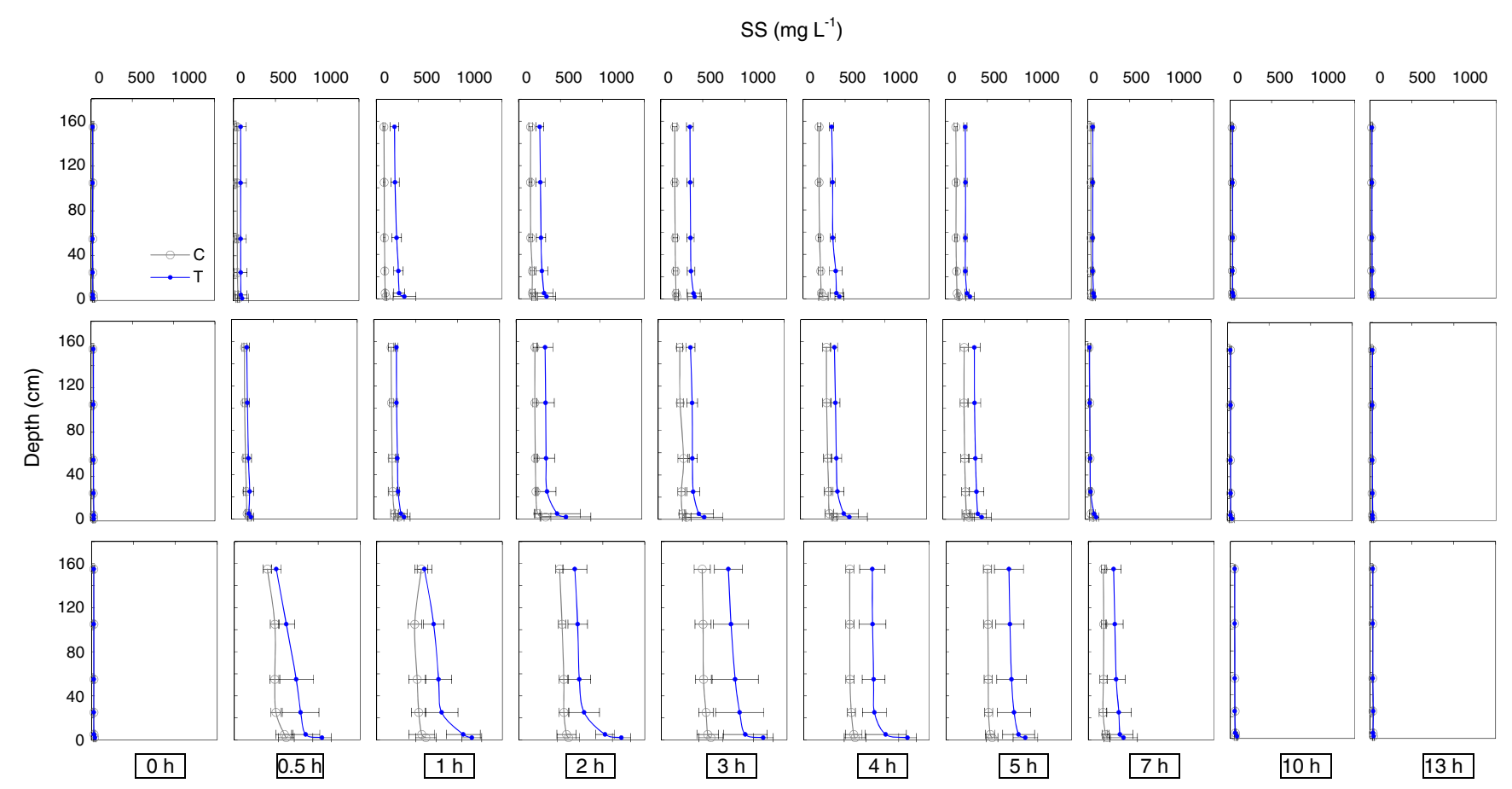

Fig. 3. Vertical distribution of suspended solids (SS) in the water column in response to three wind processes: light wind (upper panel), moderate wind (middle panel) and strong wind (lower panel). $\mathrm{C}=$ control treatment, $\mathrm{T}=$ tubificid worms treatment. Results are expressed as the means $\pm \mathrm{SD}(n=3)$.

each apparatus. The aerators were removed temporarily during the resuspension experiments. Over the next 3 days, the light, moderate and strong wind processes were simulated in sequence. During the wind and sedimentation processes, the SS in the overlying water was examined directly with an SS detector (Partech 740, UK) at 2, 5, 25, 55,105 and $155 \mathrm{~cm}$ above the sediment-water interface. The room temperature was maintained at $20 \pm 2{ }^{\circ} \mathrm{C}$ during the resuspension experiment.

At the fourth hour of the strong wind process, $500 \mathrm{~mL}$ of overlying water containing SS was sampled from each water column for particle size analysis. After the resuspension experiment, the sediment cores were unloaded and $0-0.5 \mathrm{~cm}$ of the surface sediment was collected and dried at $105^{\circ} \mathrm{C}$ to a constant dry weight. The sediment water content (W, \%) was calculated on the basis of the difference between the wet and dry weights of the sediment. The SS particle size distribution in the overlying water was examined with a laser size analyser (Malvern Mastersizer 2000, UK). The particle size parameters, $d(0.5)$ and $d(0.9)$, representing the mesh diameters through which 50 and $90 \%$ of the particles passed, respectively, were also calculated.

\section{Calculation and statistical analysis}

The total suspended solids (TSS, g.m ${ }^{-2}$ ) in the water column were calculated as follows:

$$
\mathrm{TSS}=\sum_{i=1}^{n} \mathrm{SS}_{i} \times \Delta h_{i}
$$

where $\mathrm{SS}_{i}$ is the concentration of $\mathrm{SS}$ in water layer $i\left(\mathrm{~g} \cdot \mathrm{m}^{-3}\right)$ and $\Delta h_{i}$ is the depth of layer $i$ in the water column (m).

For TSS under each wind process, the difference between the $\mathrm{C}$ and $\mathrm{T}$ treatments was tested with a twoway analysis of variance (ANOVA) with treatment and time as two factors. The differences in water content and particle size parameter $(d(0.5)$ and $d(0.9))$ between treatments $\mathrm{C}$ and $\mathrm{T}$ were analyzed with a one-way ANOVA. The statistical analysis was performed using the SPSS software package (SPSS 13.0, USA).

\section{Results}

The activities of tubificid worms changed the sediment structure. Many tiny holes inhabited by worms could be seen along the Plexiglas tubes. The worms also excreted fecal pellets onto the sediment surface. After 2 months, the height of the sediment cores inhabited by worms increased by $1.27 \pm 0.07 \mathrm{~cm}(n=3)$ compared with the control treatment cores.

The wind processes resulted in similar resuspension and sedimentation processes for both the $\mathrm{C}$ and $\mathrm{T}$ treatments (Fig. 3). In the wind processes, the SS in the water column increased with time and reached its highest density at the third or fourth hour. The SS then decreased slightly with a decreased wind speed. When the wind processes ended (at the fifth hour), the SS decreased quickly over the subsequent $2 \mathrm{~h}$ and then gradually reached the level prior to the wind process during the last $6 \mathrm{~h}$ (7th-13th hour). The SS concentrations at different 
sites were similar in the upper water column, and the SS concentrations in the lower layers were higher than those in the upper layers. The light wind resulted in the lowest SS concentration in the water column, the strong wind resulted in the highest SS, and the SS in the moderate process was between the results of the light and strong winds. Compared with the $\mathrm{C}$ treatment, the worms created higher SS concentrations in the $\mathrm{T}$ treatments in response to all wind processes.

The calculated results indicated that tubificids significantly increased the TSS in the overlying water in the wind processes (Fig. 4 and Table 1). For example, TSS values were increased by $82.7,33.8$, and $51.7 \%$ at the fourth hour in light, moderate and strong wind processes, respectively. During the sedimentation process, the TSS in both treatments decreased quickly and became similar. The resuspension and sedimentation processes caused a significant change in SS over time (Fig. 4 and Table 1).

Tubificids changed the particle size distribution of SS in the water column (Fig. 5(a)). Specifically, the worms caused a decrease in the SS diameter compared with the $\mathrm{C}$ treatment, as indicated by the significant differences in $d(0.5)$ and $d(0.9)$ between the $\mathrm{C}$ and $\mathrm{T}$ treatments (Fig. 5(b)). The water content in the $\mathrm{T}$ treatments increased by $11.2 \%$ compared with the $\mathrm{C}$ treatment (Fig. 6).

\section{Discussion}

Sediment supplies living place for benthic animals, on the other hand, benthic animals alter the sediment structure and the biogeochemical cycling in sediment or across the sediment-water interface (Welsh, 2003; Nogaro et al., 2006). As we know, sediment resuspension is also an important process influencing the biogeochemical cycling in aquatic ecosystem (You et al., 2007a, 2007b; Kalnejais et al., 2010). So, it is interesting to understand the role of benthic animals in sediment resuspension, which will give us more profound cognition in aquatic biogeochemistry. Some fishes and macroinvertebrates have been verified to influence sediment resuspension, and diverse results have been reported because they have different modifications on sediment erodibility (Flecker, 1996; Widdows et al., 2002; Scheffer et al., 2003; Orvain et al., 2006; Statzner, 2012; Lin and $\mathrm{Wu}, 2013$ ).

Tubificid worms ingest sediment particles at depth and defecate onto the sediment surface when they have burrowed into the sediment (Davis, 1974b; Kaster et al., 1984). Their defecation rate is surprising; for example, the volume of sediment defecated by tubificids is $17 \mathrm{~mL}$ per worm per year at $10^{\circ} \mathrm{C}$ (Davis, 1974a), and the defecated mass is $0.69 \mathrm{mg}$ of fecal pellets per $\mathrm{mg}$ of dry worms per $\mathrm{h}$ (Kaster et al., 1984). Owing to the worms' high defecation rate, a large quantity of fecal pellets cluster on the sediment surface. In addition, tubificids successively undulate their bodies to meet their respiration needs, which create tiny galleries in the sediment. Thus, tubificids loosen sediment consolidation (they increased the sediment height by $1.27 \mathrm{~cm}$ ) and increase the water content
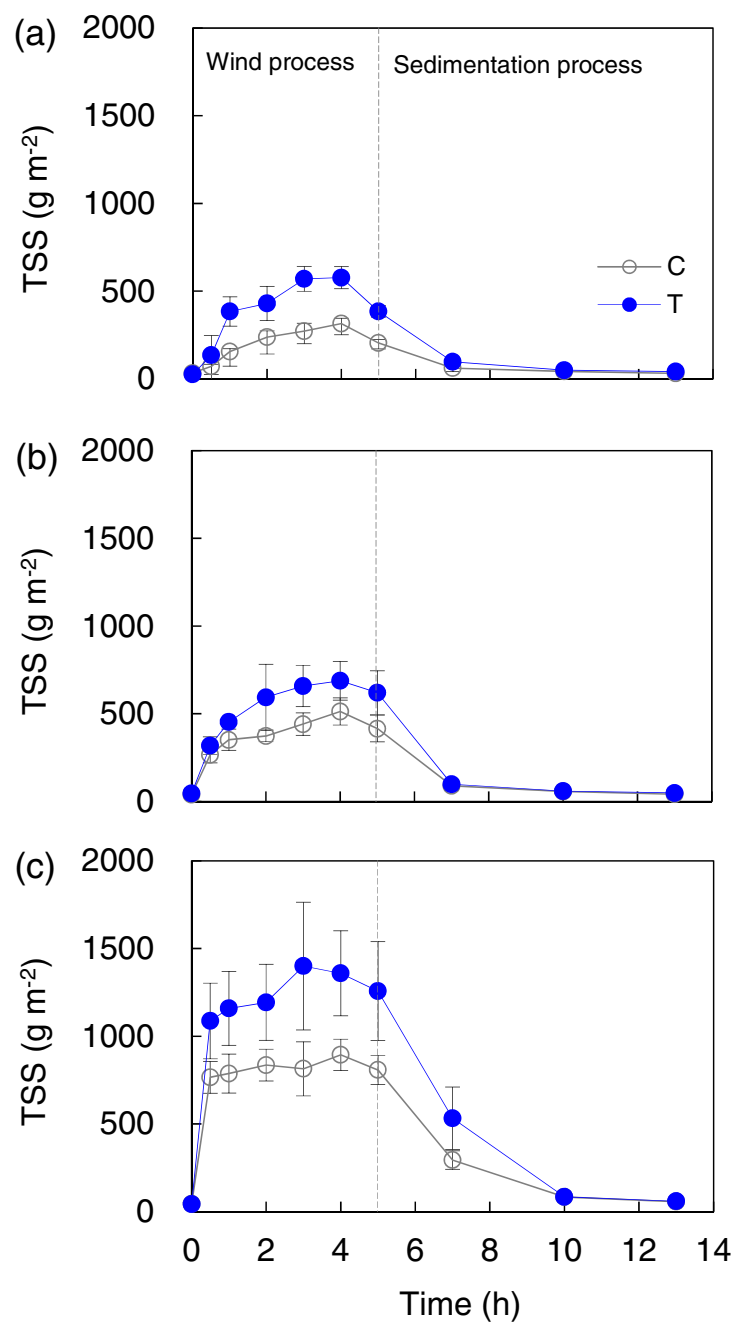

Fig. 4. Total suspended solids (TSS) in the water column in response to three wind processes: light wind (a), moderate wind (b) and strong wind (c). $\mathrm{C}=\mathrm{control}$ treatment, $\mathrm{T}=$ tubificid worms treatment. Results are expressed as the means $\pm \mathrm{SD}$ $(n=3)$.

(Fig. 6) and hydraulic conductivity of the sediment, in agreement with previous studies (Fukuhara, 1987; Nogaro et al., 2006). The degree of consolidation is a key factor in determining sediment erodibility, and sediment with a higher water content is more likely to be eroded (Bale et al., 2006; de Lucas Pardo et al., 2013). The effect of tubificids on sediment water content and consolidation is thus a key reason for the increased sediment resuspension observed in our study. This result is in accordance with other studies investigating bivalves, snails, polychaetes and ghost shrimp (Widdows et al., 2000, 2009; Orvain et al., 2006; Amaro et al., 2007).

Furthermore, the clusters of fecal pellets on the sediment surface are non-uniform, which results in an increased surface roughness. The rough sediment surface created by tubificids is also important for resuspension. Rough sediment is more easily resuspended than smooth sediment under the same conditions (Luettich et al., 1990). 
Table 1. Results of the two-way ANOVA for total suspended solids with treatment (control and tubificid worms) and time $(0,0.5$, 1 , $2,3,4,5,7,10$ and $13 \mathrm{~h}$ ) as factors.

\begin{tabular}{|c|c|c|c|c|}
\hline Wind & Factor & d.f. & $F$ & $P$ \\
\hline \multirow[t]{3}{*}{$\overline{\text { Light }}$} & Treatment & 1 & 104 & $<0.001^{* * *}$ \\
\hline & Time & 9 & 70.2 & $<0.001 * * *$ \\
\hline & Treatment $\times$ time & 9 & 8.84 & $<0.001 * * *$ \\
\hline \multirow[t]{3}{*}{ Moderate } & Treatment & 1 & 28.3 & $<0.001 * * *$ \\
\hline & Time & 9 & 60.0 & $<0.001 * * *$ \\
\hline & Treatment $\times$ time & 9 & 2.60 & $<0.05^{*}$ \\
\hline \multirow[t]{3}{*}{ Strong } & Treatment & 1 & 45.6 & $<0.001 * * *$ \\
\hline & Time & 9 & 51.6 & $<0.001 * * *$ \\
\hline & Treatment $\times$ time & 9 & 2.66 & $<0.05^{*}$ \\
\hline
\end{tabular}
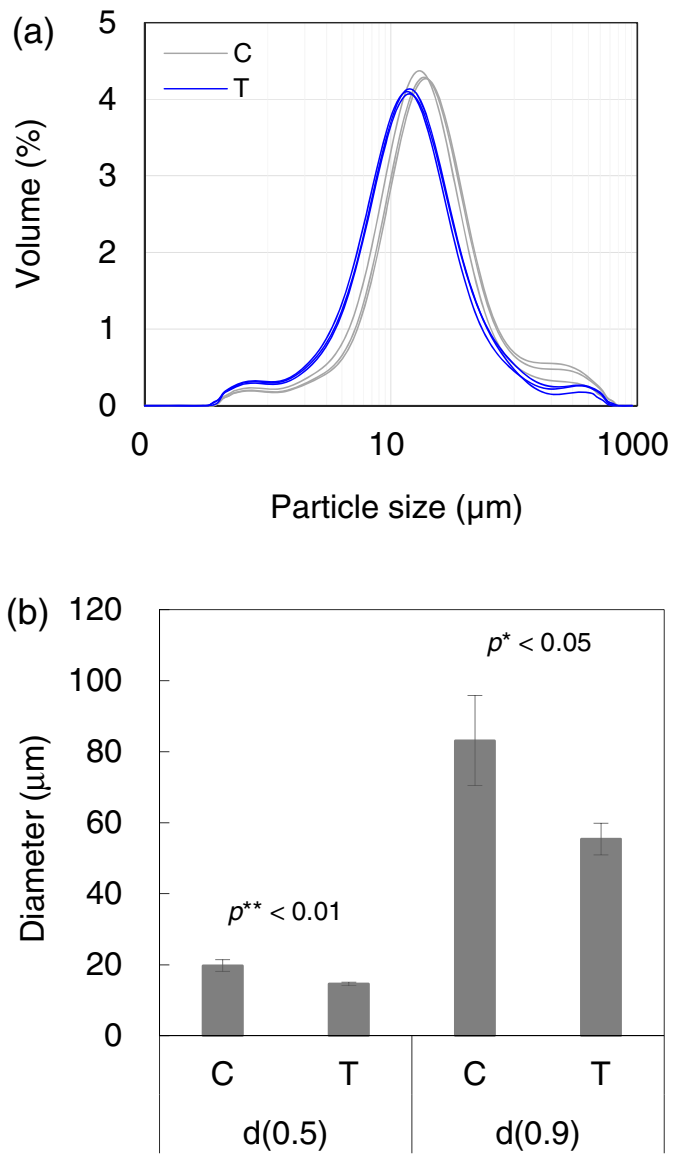

Fig. 5. Particle size distribution (a) and $d(0.5)$ and $d(0.9)$ of suspended solids from three control (C) and three tubificid worms (T) treatments (b). The $d(0.5)$ and $d(0.9)$ indicate that 50 and $90 \%$ of the particles were smaller than or equal to the respective diameter values, and results are expressed as the means $\pm \operatorname{SD}(n=3)$.

Although we created a uniform sediment surface by rotating a propeller, successive defecation roughened the sediment surface again shortly after rotation or resuspension.

In both the control and tubificid treatments, more sediment was resuspended as the wind speed increased from light to moderate to strong (Fig. 4). The high wind speed corresponded to the higher rotating speed of the

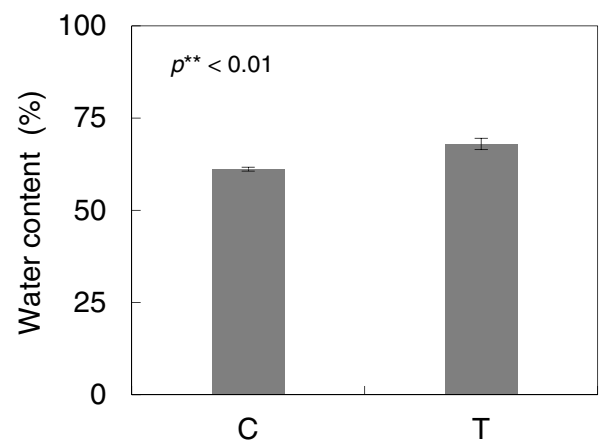

Fig. 6. Water content of the surface sediment $(0-0.5 \mathrm{~cm})$ from the control (C) and tubificid worms (T) treatments. Results are expressed as the means $\pm \mathrm{SD}(n=3)$.

electric motor, which produced a greater shear stress. Our result is in accordance with previous reports that greater shear stress causes more particles to be resuspended (Sgro et al., 2005; Bale et al., 2006; Widdows et al., 2009). It should be noted that more small particles were resuspended in the water column in the worm treatment compared with the control (Fig. 5). Tubificids increase the proportion of fine particles in the sediment surface by ingesting small particles in sediments and egesting them as fecal pellets at the sediment surface (Davis, 1974a; Rodriguez et al., 2001; Ciutat et al., 2006; Zhang, 2010). When resuspension occurs, the small particles defecated by the worms are resuspended into the water column.

The addition of benthic animals causes substantial destruction of the sediment surface, which differs from the natural state in that benthic animals act as an intrinsic part of the sediment. It was previously reported that unionid mussels (A. ligamentina and $P$. fasciolaris) decreased sediment stability in the first week after they were introduced into the sediment but increased sediment stability after 2 weeks (Zimmerman and de Szalay, 2007). The polychaete Nereis diversicolor did not influence the critical erosion velocity after $24 \mathrm{~h}$ of incubation (Widdows et al., 2009); however, Fernandes et al. (2006) found that this species increased sediment stability (critical erosion velocity) after 20 days of incubation. A small time span (e.g., $24 \mathrm{~h}$ ) is not enough for sediment to achieve a realistic state after the introduction of benthic animals (Grabowski et al., 2011). For this reason, the worms were incubated 
for 2 months in our study to allow them to arrive at a stable state.

Both sediment resuspension and bioturbation by benthic animals occur repeatedly in aquatic ecosystems. Thus, interactions between resuspension and bioturbation also occur repeatedly. The frequency of occurrence may be mainly determined by sediment resuspension, as bioturbation and the metabolism of benthic animals are more continuous than resuspension usually. This pattern is especially true for tubificids, because of their continuous ingestion, egestion, undulating movements and high densities in the sediment. The remarkable modification by tubificids on the sediment surface in still water after 2 months of incubation was not observed in the natural sediment in Lake Taihu, as this lake suffers frequent, typically daily, resuspension events (You et al., 2007a). Therefore, before the microcosms were transferred into the Y-shape resuspension apparatus in the present study, the sediment surfaces of the tubificid treatments were disturbed slightly with a hand-held propeller to obtain a smooth surface. We believe this procedure enabled the resuspension simulation in the subsequent 3 days to more closely match the natural conditions in Lake Taihu.

Our results clearly indicate that tubificid worms enhance sediment resuspension. Sediment resuspension is an important process for oxygen and nutrient dynamics in aquatic ecosystems (Schallenberg and Burns, 2004; You et al., 2007b; Tammeorg et al., 2013). Tubificid worms and other benthic animals also significantly influence the oxygen and nutrient dynamics in the water, sediment and across the sediment-water interface (Lewandowski and Hupfer, 2005; Mermillod-Blondin et al., 2005; Zhang et al., 2010). For the importance of oxygen, nitrogen and phosphorus in global element cycling and eutrophication, the influence of the interactions between resuspension and benthic animals on oxygen and nutrient dynamics should be investigated in future studies.

Acknowledgements. This study was funded by the National Natural Science Foundation of China (grant no. 41103033) and the Basic Research Program of Jiangsu Province (grant no. BK2011879). We sincerely thank Juhua $\mathrm{Yu}$ for his kind assistance in the laboratory.

\section{References}

Amaro T.P.F., Duineveld G.C.A., Bergman M.J.N., Witbaard R. and Scheffer M., 2007. The consequences of changes in abundance of Callianassa subterranea and Amphiura filiformis on sediment erosion at the Frisian Front (southeastern North Sea). Hydrobiologia, 589, 273-285.

Bale A.J., Widdows J., Harris C.B. and Stephens J.A., 2006. Measurements of the critical erosion threshold of surface sediments along the Tamar Estuary using a mini-annular flume. Cont. Shelf Res., 26, 1206-1216.

Bloesch J., 1995. Mechanisms, measurement and importance of sediment resuspension in lakes. Mar. Freshw. Res., 46, 295-304.
Cai Y., Gong Z. and Qin B., 2010. Community structure and diversity of macrozoobenthos in Lake Taihu, a large shallow eutrophic lake in China. Biodivers. Sci., 18, 50-59.

Ciutat A., Weber O., Gérino M. and Boudou A., 2006. Stratigraphic effects of tubificids in freshwater sediments: a kinetic study based on X-ray images and grain-size analysis. Acta Oecol., 30, 228-237.

Couceiro F., Fones G.R., Thompson C.E.L., Statham P.J., Sivyer D.B., Parker R., Kelly-Gerreyn B.A. and Amos C.L., 2013. Impact of resuspension of cohesive sediments at the Oyster Grounds (North Sea) on nutrient exchange across the sediment-water interface. Biogeochemistry, 113, 37-52.

Dafoe L.T., Rygh A.L., Yang B., Gingras M.K. and Pemberton S.G., 2011. A new technique for assessing tubificid burrowing activities, and recognition of biogenic grading formed by these oligochaetes. Palaios, 26, 66-80.

Davis R.B., 1974a. Stratigraphic effects of tubificids in profundal lake sediments. Limnol. Oceanogr., 19, 466-488.

Davis R.B., 1974b. Tubificids alter profiles of redox potential and $\mathrm{pH}$ in profundal lake sediment. Limnol. Oceanogr., 19, 342-346.

de Lucas Pardo M.A., Bakker M., van Kessel T., Cozzoli F. and Winterwerp J.C., 2013. Erodibility of soft freshwater sediments in Markermeer: the role of bioturbation by meiobenthic fauna. Ocean Dyn., 63, 1137-1150.

de Vicente I., Cruz-Pizarro L. and Rueda F.J., 2010. Sediment resuspension in two adjacent shallow coastal lakes: controlling factors and consequences on phosphate dynamics. Aquat. Sci., 72, 21-31.

Evans R.D., 1994. Empirical evidence of the importance of sediment resuspension in lakes. Hydrobiologia, 284, 5-12.

Fernandes S., Sobral P. and Costa M.H., 2006. Nereis diversicolor effect on the stability of cohesive intertidal sediments. Aquat. Ecol., 40, 567-579.

Flecker A.S., 1996. Ecosystem engineering by a dominant detritivore in a diverse tropical stream. Ecology, 77, 1845-1854.

Fukuhara H., 1987. The effect of tubificids and chironomids on particle redistribution of lake sediment. Ecol. Res., 2, 255-264.

Grabowski R.C., Droppo I.G. and Wharton G., 2011. Erodibility of cohesive sediment: the importance of sediment properties. Earth-Sci. Rev., 105, 101-120.

Hu C., Hu W., Zhang F., Hu Z., Li X. and Chen Y., 2006. Sediment resuspension in the Lake Taihu, China. Chin. Sci. Bull., 51, 731-737.

James W.F., Best E.P. and Barko J.W., 2004. Sediment resuspension and light attenuation in Peoria Lake: can macrophytes improve water quality in this shallow system? Hydrobiologia, 515, 193-201.

Kalnejais L.H., Martin W.R. and Bothner M.H., 2010. The release of dissolved nutrients and metals from coastal sediments due to resuspension. Mar. Chem., 121, 224-235.

Kang Y., Song X. and Liu Z., 2013. Sediment resuspension dampens the effect of nutrient inputs on the phytoplankton community: a mesocosm experiment study. Hydrobiologia, 710, 117-127.

Kaster J., Val Klump J., Meyer J., Krezoski J. and Smith M., 1984. Comparison of defecation rates of Limnodrilus hoffmeisteri Claparède (Tubificidae) using two different methods. Hydrobiologia, 111, 181-184. 
Lewandowski J. and Hupfer M., 2005. Effect of macrozoobenthos on two-dimensional small-scale heterogeneity of pore water phosphorus concentrations in lake sediments: a laboratory study. Limnol. Oceanogr., 50, 1106-1118.

Lin Y.-T. and Wu C.H., 2013. Response of bottom sediment stability after carp removal in a small lake. Ann. Limnol. Int. J. Lim., 49, 157-168.

Luettich R.A., Harleman D.R.F. and Somlyody L., 1990. Dynamic behavior of suspended sediment concentrations in a shallow lake perturbed by episodic wind events. Limnol. Oceanogr., 35, 1050-1067.

Matisoff G., Fisher J. and Matis S., 1985. Effects of benthic macroinvertebrates on the exchange of solutes between sediments and freshwater. Hydrobiologia, 122, 19-33.

Matisoff G., Wang X. and McCall P.L., 1999. Biological redistribution of lake sediments by tubificid oligochaetes: Branchiura sowerbyi and Limnodrilus hoffmeisteri/Tubifex tubifex. J. Great Lakes Res., 25, 205-219.

Mermillod-Blondin F., Nogaro G., Datry T., Malard F. and Gibert J., 2005. Do tubificid worms influence the fate of organic matter and pollutants in stormwater sediments? Environ. Pollut., 134, 57-69.

Nogaro G., Mermillod-Blondin F., François-Carcaillet F., Gaudet J.-P., Lafont M. and Gibert J., 2006. Invertebrate bioturbation can reduce the clogging of sediment: an experimental study using infiltration sediment columns. Freshw. Biol., 51, 1458-1473.

Nogaro G., Mermillod-Blondin F., Montuelle B., Boisson J.-C., Lafont M., Volat B. and Gibert J., 2007. Do tubificid worms influence organic matter processing and fate of pollutants in stormwater sediments deposited at the surface of infiltration systems? Chemosphere, 70, 315-328.

Orvain F., Sauriau P.G., Bacher C. and Prineau M., 2006. The influence of sediment cohesiveness on bioturbation effects due to Hydrobia ulvae on the initial erosion of intertidal sediments: a study combining flume and model approaches. J. Sea Res., 55, 54-73.

Qin B., 2008. Lake Taihu, China: Dynamics and Environmental Change, Springer, The Netherlands.

Rodriguez P., Martinez-Madrid M. and Arrate J.A., Navarro E., 2001. Selective feeding by the aquatic oligochaete Tubifex tubifex (Tubificidae, Clitellata). Hydrobiologia, 463, 133-140.

Schallenberg M. and Burns C.W., 2004. Effects of sediment resuspension on phytoplankton production: teasing apart the influences of light, nutrients and algal entrainment. Freshwat. Biol., 49, 143-159.

Scheffer M., Portielje R. and Zambrano L., 2003. Fish facilitate wave resuspension of sediment. Limnol. Oceanogr., 48, 19201926.

Sgro L., Mistri M. and Widdows J., 2005. Impact of the infaunal Manila clam, Ruditapes philippinarum, on sediment stability. Hydrobiologia, 550, 175-182.

Song X., Liu Z., Yang G. and Chen Y., 2010. Effects of resuspension and eutrophication level on summer phytoplankton dynamics in two hypertrophic areas of Lake Taihu, China. Aquat. Ecol., 44, 41-54.
Sorokina V. and Kulygin V., 2013. Long-term variability of the water transparency (Secchi Depth) in the Sea of Azov. Oceanology, 53, 287-293.

Statzner B., 2012. Geomorphological implications of engineering bed sediments by lotic animals. Geomorphology, 157-158, 49-65.

Superville P.-J., Prygiel E., Magnier A., Lesven L., Gao Y., Baeyens W., Ouddane B., Dumoulin D. and Billon G., 2014. Daily variations of $\mathrm{Zn}$ and $\mathrm{Pb}$ concentrations in the Deûle River in relation to the resuspension of heavily polluted sediments. Sci. Total Environ., 470, 600-607.

Tammeorg O., Niemistö J., Möls T., Laugaste R., Panksep K. and Kangur K., 2013. Wind-induced sediment resuspension as a potential factor sustaining eutrophication in large and shallow Lake Peipsi. Aquat. Sci., 75, 559-570.

Welsh D., 2003. It's a dirty job but someone has to do it: the role of marine benthic macrofauna in organic matter turnover and nutrient recycling to the water column. Chem. Ecol., 19, 321-342.

Widdows J. and Brinsley M., 2002. Impact of biotic and abiotic processes on sediment dynamics and the consequences to the structure and functioning of the intertidal zone. J. Sea Res., 48, 143-156.

Widdows J., Brinsley M.D., Salkeld P.D. and Lucas C.H., 2000. Influence of biota on spatial and temporal variation in sediment erodability and material flux on a tidal flat (Westerschelde, The Netherlands). Mar. Ecol. Prog. Ser., 194, 23-37.

Widdows J., Lucas J.S., Brinsley M.D., Salkeld P.N. and Staff F.J., 2002. Investigation of the effects of current velocity on mussel feeding and mussel bed stability using an annular flume. Helgoland Mar. Res., 56, 3-12.

Widdows J., Brinsley M.D. and Pope N.D., 2009. Effect of Nereis diversicolor density on the erodability of estuarine sediment. Mar. Ecol. Prog. Ser., 378, 135-143.

Yang Z., Feng J., Niu J. and Shen Z., 2008. Release of polycyclic aromatic hydrocarbons from Yangtze River sediment cores during periods of simulated resuspension. Environ. Pollut., $155,366-374$.

You B., Wang T., Fan C., Zhu L., Zhong J., Li B., Yin H. and Hu C., 2007a. Quantitative simulative method of sediment resuspension in Lake Taihu. J. Lake Sci., 19, 611-617.

You B., Zhong J., Fan C., Wang T., Zhang L. and Ding S., 2007b. Effects of hydrodynamics processes on phosphorus fluxes from sediment in large, shallow Taihu Lake. J. Environ. Sci., 19, 1055-1060.

Zhang L., 2010. Changes of Sediment-Water Interface Properties and Phosphorus Dynamics Under Bioturbation in Lake, Nanjing Institute of Geography and Limnology, CAS, Nanjing.

Zhang L., Gu X., Fan C., Shang J., Shen Q., Wang Z. and Shen J., 2010. Impact of different benthic animals on phosphorus dynamics across the sediment-water interface. J. Environ. Sci., 22, 1674-1682.

Zimmerman G.F. and de Szalay F.A., 2007. Influence of unionid mussels (Mollusca: Unionidae) on sediment stability: an artificial stream study. Fund. Appl. Limnol., 168, 299-306. 